\title{
CZY RZECZYWIŚCIE NAJSTARSZE - WERYFIKACYJNE BADANIA NAJWCZEŚNIEJ DATOWANYCH GRÓDKÓW STOŻKOWATYCH
}

SŁowa KLuCzowe: archeologia, średniowiecze, dwór rycerski, gródek stożkowaty KeYwords: archeology, Middle Ages, knight's manor, Motte and bailey

Badania archeologiczne grodzisk zazwyczaj nazywanych stożkowaty$\mathrm{mi}^{1}$ - ale też coraz częściej obiektami typu motte - na szerszą skalę rozpoczęły się w Polsce na przełomie lat sześćdziesiątych i siedemdziesiątych XX w. Wówczas też zaczęła rozwijać się nowa specjalizacja - archeologia późnego średniowiecza. Meandry prób wypracowania własnej metodyki i metodologii badań stanowisk z czasów w pełni historycznych stały się tematem wielu prac. Wykopaliska prowadzone na gródkach stożkowatych również doczekały się krytycznych omówień (Kajzer 1977; 1995; 1997; 1998; Marciniak-Kajzer 2011; 2016; Nowakowski 2017). Jednym z najbardziej znaczących kłopotów, jakie pojawiają się przy próbach posumowania badań tych obiektów, jest ich datowanie. O tym, że wymaga ono gruntownej weryfikacji starałam się wykazać już w dwóch swoich pracach, dlatego też nie będę tu ponownie przytaczała zawartych tam argumentów (Marciniak-Kajzer 2011; 2016). Dwory na kopcach, czyli obiekty typu motte lub, jak piszą Anglicy motte castles, to paneuropejski typ obronnej siedziby związanej z procesem feudalizacji społeczeństw. Zgodnie z tym, co przyjęto w literaturze zachodniej, powstawały one na przełomie X i XI w. we Francji, choć z tym twierdzeniem można dyskutować. Z pewnością największą popularnością cieszyły się na Wyspach Brytyjskich, gdzie ich budowę na wielką skalę rozpoczęły wojska Wilhelma Zdobywcy po podboju w $1066 \mathrm{r}$. Ich pojawienie się na ziemiach polskich datowane jest na wiek XIII. Niestety ilość stanowisk, dla których udało się uzyskać daty

\footnotetext{
${ }^{1}$ Artykuł napisany w ramach realizacji grantu NCN 2013/09/B/HS3/03572.
} 
bezwzględne, nie przekracza kilkunastu. Nie są to dodatkowo obiekty uznane za najstarsze.

Potrzeba weryfikacji chronologii wielu stanowisk badanych przed kilkudziesięciu laty jest wśród archeologów powszechnie zauważana i postulowana. Pozostaje jednak pytanie - jak to zrobić?

Przed kilkunastu laty Instytut Archeologii Uniwersytetu Łódzkiego podjął współpracę z Jarosławem Kusiakiem pracownikiem laboratorium Zakładu Geografii Fizycznej i Paleogeografii Instytutu Nauk o Ziemi Uniwersytetu Marii Curie-Skłodowskiej w Lublinie. Wykonywał on dla archeologów datowania metodą termoluminescencyjną. Początkowo nastawieni sceptycznie, ze względu na małą precyzję tej metody, dość szybko przekonaliśmy się, że wypracował on procedury pozwalające na osiągnięcie znacznej dokładności. Datowanie metodą termoluminescencyjną, pomimo, iż mniej czułe niż np. dendrochronologia, może być powszechnie stosowane, $\mathrm{z}$ tego prostego powodu, że badane są wyroby ceramiczne - dostępne w zasadzie na każdym stanowisku.

W tym czasie powstał pomysł podjęcia próby weryfikacji chronologii tych gródków stożkowatych, które uznano za najstarsze. Uzyskałam na ten cel grant Narodowego Centrum Nauki. Niestety w początkowej fazie realizacji projektu J. Kusiak zmarł. Jak się okazało, we wspomnianym laboratorium nie ma obecnie osób mogących wykonać podobne pomiary. Spowodowało to konieczność zmiany wcześniej ustalonej procedury typowania stanowisk do badań. Teraz należało się skupić na tych obiektach, na których istniała potencjalna możliwość pozyskania materiałów organicznych, również do innych analiz datujących.

$\mathrm{W}$ ramach projektu na kilku wytypowanych stanowiskach wykonaliśmy badania weryfikacyjne w celu pobrania próbek do wszelkich możliwych badań laboratoryjnych, które mogły dostarczyć dat bezwzględnych. Oczywiście najcenniejszym, bo dającym szansę na wyjątkowo precyzyjne datowanie, byłoby pozyskanie drewna do badań dendrochronologicznych, jednakże, jak wszyscy wiemy, było to stosunkowo mało prawdopodobne. Znacznie większe szanse mieliśmy na pobranie organicznych próbek do badań izotopu ${ }^{14} \mathrm{C}$. Materiał ceramiczny do badań termoluminescencyjnych był dostępny na każdym stanowisku, jednak przewidywaliśmy kłopoty $\mathrm{z}$ otrzymaniem precyzyjnego datowania $\mathrm{w}$ innym laboratorium, niż wspomniane powyżej.

Dzięki informacjom zdobytym w trakcie kwerendy przeprowadzonej w literaturze wybrano stanowiska będące typowymi „gródkami stożkowatymi”, które w wyniku wcześniejszych badań wykopaliskowych datowano na XIII w. Dodatkowym kryterium była możliwość pozyskania drewna lub innych materiałów organicznych, co staraliśmy się wywnioskować na podstawie sprawozdań z wcześniejszych badań.

Ostateczna lista wytypowanych stanowisk wygląda następująco: trzy stanowiska zlokalizowane są w województwie mazowieckim: Kiełbów Stary, gm. Sta- 
ra Błotnica, Orszymowo, gm. Mała Wieś i Wilkanowo (dawniej Nakwasin) położone również w gm. Mała Wieś. Następne dwa znajdują się w województwie łódzkim: Witów, gm. Burzenin i Małków, gm. Warta. Kolejne prace przeprowadzono w Sędziszowie (dzisiaj na terenie wsi Piła) w woj. świętokrzyskim, w Piekarach, gm. Dobra, woj. wielkopolskie oraz w Szczekocinach, w woj. śląskim.

Badania rozpoczęliśmy od zebrania pełnej bibliografii i wszelkiej dostępnej dokumentacji archiwalnej z wcześniejszych prac archeologicznych znajdujących się w delegaturach Wojewódzkich Urzędów Ochrony Zabytków. Niestety, nie dla wszystkich stanowisk były to pełne opracowania. Kolejnym etapem działań było wykonanie planów sytuacyjno-wysokościowych. Nowe pomiary geodezyjne pokazały zmiany w stanie zachowania badanych obiektów. Niestety na większości z nich można zaobserwować ślady pogłębiającej się destrukcji. W przypadku Kiełbowa i Sędziszowa jest to kopanie dołów na śmieci. W Szczekocinach stanowisko zostało otoczone stawami rybnymi, które zniszczyły część fosy, podobnie jak w Wilkanowie, gdzie wykopanie zbiornika retencyjnego doprowadziło do zatarcia pierwotnego układu hydrologicznego.

W pierwszym sezonie badań - w roku 2014 - prace przeprowadzono na grodziskach w Orszymowie, Wilkanowie, Małkowie i Witowie. W roku 2015 wykopaliska miały miejsce w Kiełbowie, Piekarach, Sędziszowie i Szczekocinach. Na większości stanowisk wykonano jeden wykop badawczy. Wyjątkiem było stanowisko w Kiełbowie Starym, gdzie pierwszy z wykopów wytyczono w miejscu starego, eksplorowanego najprawdopodobniej w $1965 \mathrm{r}$.

Przyjrzyjmy się pokrótce wynikom omawianych badań.

Jedno ze stanowisk - niezwykle interesujące - opiszę dokładniej. Grodzisko w Orszymowie znajduje się na krawędzi niewielkiego wzniesienia na prawym brzegu doliny strumienia Ryksa, prawego dopływu Wisły. Kopiec ma średnicę podstawy 36-38 m i wysokość około $6 \mathrm{~m}$. Na szczycie znajduje się zgłębiona platforma o średnicy $15 \mathrm{~m}$.

W Orszymowie w 1966 r. jeden wykop eksplorował Wojciech Szymański. Ponieważ, jak wynika z opublikowanych planów, zajmował on północno-zachodnią część typowego dla takich stanowisk centralnego „zaklęśnięcia”, postanowiliśmy ulokować nasz wykop przy krawędzi „kotlinki” w części południowej kopca. Miejsce wybrano tak, aby obserwować zarówno nawarstwienia w tej część plateau, jak również stok „kotlinki”. Wykop o wymiarach 3 x 4 m wytyczono w taki sposób, że jego dłuższy bok znajdował się na linii północ - południe z $10^{\circ}$ odchyleniem na zachód. Niewielkie odchylenie spowodowane było chęcią prostopadłego usytuowania wykopu względem stoków „zaklęśnięcia”. Dysponowaliśmy dwiema publikacjami (Szymański 1966; 1968) relacjonującymi przebieg wcześniejszych prac i ku naszemu szczeremu podziwowi okazało się, że opisy są tak precyzyjne, że mogliśmy z dokładnością do kilku centymetrów przewidzieć zmianę warstwy. 
Poniżej warstwy humusu, początkowo na całej powierzchni wykopu pojawiła się ciemna, piaszczysta próchnica z niewielkimi wtrętami drobnych węgielków i nielicznymi zabytkami [3]. W części południowej wykopu miała ona niewielką grubość $15-25 \mathrm{~cm}$ i upadała w kierunku północnym równolegle do nachylenia stoków „kotlinki”, zwiększając znacznie swoją miąższość tak, że przy profilu północnym osiągała około $105 \mathrm{~cm}$.

Poniżej zalegała ciemna próchnica zawierająca znaczną domieszkę kawałków węgli drzewnych i grudek polepy [6]. Przy profilu południowym miała ona miąższość około 20-30 cm w części zachodniej i była nieco grubsza (do $40 \mathrm{~cm}$ ) w partii wschodniej. Warstwa ta upadała w kierunku północnym, zmniejszając jednocześnie swoją miąższość. Przy profilu zachodnim, mniej więcej w połowie wykopu, nieomalże zanikała. Dalej na północ jej upad był gwałtowniejszy i ponownie jej miąższość wzrastała. Po przeanalizowaniu układu stratygraficznego możemy domniemywać, że powstała ona w momencie destrukcji budynku w wyniku pożaru. Początkowo zalegała wokół niego na poziomie ówczesnej powierzchni użytkowej. Następnie, po zapadnięciu się pogorzeliska, stopniowo spływała do zniszczonego przyziemia (piwnicy?) budynku.

Pod opisaną powyżej warstwą, w południowej partii wykopu zalegał szarożółty gliniasty piasek, który został zinterpretowany jako pierwotny nasyp kopca. W tej części miał on bardzo dużą miąższość osiągającą $170 \mathrm{~cm}$ [2].

W środkowej części wykopu obserwowano nieco inny układ stratygraficzny. Na głębokości niwelacyjnej około 114,49 m n.p.m., bezpośrednio pod ciemną próchnicą zawierającą znaczną domieszkę kawałków węgli drzewnych i grudek polepy [6], pojawiła się twarda, zbita, jasna glina [4]. Przebiegała ona początkowo pasem w poprzek wykopu po linii wschód - zachód. Tym samym wykop został podzielony prawie na pół. Jednocześnie eksplorowano trzy typy wypełniska. W części południowej warstwę szarożółtego piasku nasypowego [2], poprzeczny pas twardej gliny [4], a w części północnej, początkowo jeszcze warstwę ciemnej, piaszczystej próchnicy [3], a pod nią ciemną próchnicę zawierającą znaczną domieszkę kawałków węgli drzewnych i grudek polepy [6]. Niżej pas gliny poszerzał się. Na wysokości niwelacyjnej około 114,14 m n.p.m. pojawiły się w nim pierwsze kamienie eratyczne. Również one tworzyły pas w poprzek wykopu. Stopniowo kamieni przybywało, część z nich usunięto. Od głębokości 114,04 m n.p.m., pas kamieni ograniczała od strony północnej najpierw słabo się rysująca, ale następnie coraz szersza i bardziej intensywna w zabarwieniu warstwa czarnych węgli drzewnych [14]. Pas ten stanowił granicę dwóch różnych typów wypełniska. Po jego stronie północnej, poniżej warstwy [6], pojawiła się soczewkowata w kształcie warstwa jasnej gliny, jednak już z niewielką domieszką węgli drzewnych i drobnych grudek polepy [4a].

Późniejsze, pełne przeanalizowanie omówionego układu stratygraficznego, widocznego również na profilach, pozwala wysunąć przypuszczenie, że war- 
stwa spalenizny [14] to relikt spalonej ściany budynku. Twarda glina, wraz z kamieniami [4], przylegająca do tych pozostałości od strony zewnętrznej (południowej), stanowiła pierwotnie umocnienie ścian przed rozsunięciem. Glina na wtórnym złożu [4a], spłynęła do zasypanego wnętrza budynku po jego destrukcji i zawaleniu się ścian.

Kamienna „ława” o szerokości 120-130 cm, na głębokości około 113,54 m n.p.m. zajmowała pas wzdłuż południowej ściany wykopu. Biorąc pod uwagę skosy pozostawione w celu zabezpieczenia przed osunięciem się profilu - było to $170 \mathrm{~cm}$ od wytyczonego boku wykopu. Ponieważ W. Szymański w swoim sprawozdaniu z 1966 r. również odkrył „ławę” o podobnej szerokości, po zakończeniu eksploracji i narysowaniu profili, wyrównaliśmy południową ścianę wykopu „do pionu” aby sprawdzić, czy napotkamy jej kontynuację. Okazało się, że całość tej konstrukcji znalazła się w granicach naszego wykopu. Potwierdziło to również obserwacje z 1966 r. Podobnie jak W. Szymański, zdecydowaliśmy, że ze względu na potrzebę zachowania stanowiska, nie będziemy rozbierać tej kamiennej konstrukcji, zwłaszcza, że znajdowała się ona już na głębokości przekraczającej $220 \mathrm{~cm}$ od współczesnej powierzchni gruntu. Dalsza eksploracja miała więc miejsce w północnej części wykopu o długości około $230 \mathrm{~cm}$, którą dodatkowo zawężały skosy.

Poniżej soczewki twardej gliny [4], po wewnętrznej stronie (północnej) reliktów spalonej ściany budynku zalegał rumosz z dużych brył polepy [5/7]. Jej barwa - od jasnoczerwonej przez ceglastą do wiśniowej - przekonuje, że temperatura jaka panowała w czasie pożaru, który spowodował wypalenie się gliny, była bardzo wysoka. Niektóre bryłki miały ślady odciśniętych dranic.

Przy relikcie spalonej ściany warstwa ta [5/7] osiągała miąższość dochodzącą do $130 \mathrm{~cm}$. Podwójna numeracja tej jednostki stratygraficznej wynikała z początkowej próby rozdzielenia jej na dwie warstwy. Spowodowane to było tym, że po stronie północnej wykopu bryły polepy były słabiej wypalone i między nimi znajdowało się więcej piaszczystej próchnicy. Dlatego materiał ruchomy z tych miejsc zbierany był osobno. Po przeanalizowaniu profili, zdecydowaliśmy o połączeniu tych dwóch jednostek, ze względu na ich identyczne pochodzenie - było to rumowisko wypalonej polepy ze ścian spalonego budynku.

Na głębokości niwelacyjnej około 112,74 m n.p.m. poniżej gruzowiska polepy [5/7] odkryto czarną warstwę spalenizny. Miała ona niewielką miąższość nie przekraczającą 5-7 cm. Uznano ją za pozostałość spalonej podłogi domu [9]. Z warstwy tej pobrano próbki węgla do datowania metodą oznaczenia zawartości izotopu ${ }^{14} \mathrm{C}$. Na tej wysokości w narożniku północno-zachodnim pojawiło się skupisko kamieni eratycznych. Małe wymiary wykopu nie pozwoliły na określenie jego zasięgu. Kilkuwarstwowe skupisko kamieni, zalegających na poziomie użytkowym budynku, odkrył również W. Szymański. Ponieważ war- 
stwa gruzowa polepy osypywała się stwarzając zagrożenie osunięcia się profilu, kamieni nie usuwano i pozostawiono tu schodek ułatwiający wychodzenie z wykopu.

Poniżej poziomu domniemanej podłogi [9] zalegała warstwa żółtego piasku [11]. Osiągała ona miąższość około $50 \mathrm{~cm}$ (znaleziono w niej duży, wtórnie przepalony fragment miseczki). Pod nią, na głębokości niwelacyjnej około 112,14 m n.p.m. pojawiła się kolejna, podobna do opisanej powyżej, warstwa spalenizny. Miała ona zbliżoną miąższość. Na uwagę zasługuje jednak fakt odkrycia w niej skupisk przepalonych ziaren zbóż. Podobne znalezisko opisał również W. Szymański.

Znajdująca się poniżej warstwa to szary piasek [12]. Zawierał on drobiny węgli drzewnych. Nie odnotowano w nim materiału zabytkowego ani kamieni eratycznych, które w swoim wykopie odkrył W. Szymański. Warstwa ta może być interpretowana jako poziom próchnicy pierwotnej. Na głębokości 111,49 m n.p.m. pojawił się jasnoszary piasek calcowy [13]. Eksplorację wykopu zakończono na głębokości 111,34 m n.p.m.

Ponieważ zarówno nasze jak i wcześniejsze badania dały niezwykle spójny obraz, można z dużą dozą prawdopodobieństwa stwierdzić, że jest to niezmiernie interesujący i dodatkowo dobrze zachowany obiekt. Dalsze, szerzej zakrojone wykopaliska mogłyby przynieść znaczny przyrost wiedzy o sposobach zagospodarowania tego typu siedzib.

Ze stanowiska udało się pobrać próbki do badań ${ }^{14} \mathrm{C}$ i znaczne fragmenty polepy do analiz termoluminescencyjnych. Z. Szymański datował ten obiekt na wiek XIII.

Kolejnym stanowiskiem, które poddane zostało weryfikacji, był obiekt w sąsiednim Wilkanowie - położony w odległości niespełna $3 \mathrm{~km}$. Podobnie, jak w przypadku Orszymowa, nasze obserwacje w pełni potwierdziły dane znane nam ze sprawozdania z badań przeprowadzonych w 1966 r. przez W. Szymańskiego (1968). Na tym stanowisku odkrycia nie były jednak tak spektakularne.

Grodzisko znajduje się wśród podmokłych łąk w dolinie Ryksy, na jej prawym brzegu. Kopiec ma średnicę podstawy $27 \mathrm{~m}$ i wysokość $2 \mathrm{~m}$. Otoczony jest płytkim zabagnionym rowem o szerokości około $6 \mathrm{~m}$, który po stronie południowej, już w XX w. poszerzono, wykopując zbiornik retencyjny. Na wierzchołku stożka widoczne jest okrągłe zaklęśnięcie. Relikt wykopu z 1966 r. to obecnie wyraźnie rysujące się obniżenie przecinające całe zagłębione plateau kopca oraz wyniesioną krawędź (określaną przez W. Szymańskiego jako wał) po linii z południowego zachodu na północny wschód. Ponieważ wykop ten zajmował w zasadzie cały środek typowego dla takich stanowisk centralnego „zaklęśnięcia”, nasz wykop postanowiliśmy ulokować przy krawędzi „kotlinki” w części południowej kopca. Miejsce wybrano w taki sposób, aby uniknąć wycinania krzewów i ominąć karpy po drzewach ściętych przez bobry, których wiele znaj- 
duje się na stanowisku. Wykop o wymiarach 2 x 3 m wytyczono w taki sposób, że jego dłuższy bok znajdował się na linii północ - południe z $10^{\circ}$ odchyleniem na wschód. Krótszy bok - północny usytuowano w bezpośrednim sąsiedztwie wykopu z 1966 r.

Pod humusem, początkowo przy narożniku południowo-zachodnim, a następnie wzdłuż boku południowego wykopu znajdowała się próchniczno-piaszczysta warstwa $\mathrm{z}$ węglami drzewnymi i drobnymi kawałkami polepy. Miała ona miąższość $60-70 \mathrm{~cm}$ i upadała w kierunku północnym równolegle do nachylenia stoków „kotlinki”, zwiększając nieco swoją miąższość tak, że przy profilu północnym osiągała około $80 \mathrm{~cm}$. Poniżej zalegało gruzowisko dużych brył silnie przepalonej polepy. Miała ona barwę od jasnoczerwonej przez ceglastą do wiśniowej - można z tego wyciągnąć wniosek, że temperatura, jaka panowała w czasie pożaru, który spowodował wypalenie się gliny była bardzo wysoka. Wskazywać też na to może brak węgli drzewnych z konstrukcji ścian. Prawdopodobnie wypaliły się całkowicie, pozostawiając mniej trwały popiół. Również nieliczne fragmenty naczyń ceramicznych, jakie odnaleźliśmy w tej warstwie, noszą ślady wtórnego silnego przepalenia. W spągu warstwy gruzowej polepy na całej powierzchni wykopu zalegały kamienie eratyczne, tworzące rodzaj luźnego, miejscami dwu- i trójwarstwowego bruku. Gdzieniegdzie oblepione były gliniastą czarną próchnicą przesyconą węglami drzewnymi. Nie można było jednak wydzielić odrębnej warstwy spalenizny, jaka wystąpiła w wykopie z 1966 r. Z poczynionych obserwacji wynika jednak, że spalone drewno znajdowało się pierwotnie na kamieniach, zaciemnienia poniżej nich, to efekt naturalnego przemywania. $\mathrm{Z}$ tego poziomu pobrano próbki węgla do datowania metodą oznaczenia zawartości izotopu ${ }^{14} \mathrm{C}$.

Warstwa, w stropie której znajdowały się kamienie to szarobrunatna gliniasta próchnica $\mathrm{z}$ węglami drzewnymi i niewielką ilością materiału zabytkowego. Miejscami osiągała ona grubość do $40 \mathrm{~cm}$. Znajdowała się bezpośrednio na próchnicy pierwotnej, pod którą obserwowano piaszczysty calec. W wykopie odnaleziono znikomą ilość materiału zabytkowego - zaledwie 22 ułamki ceramiki naczyniowej i kilka fragmentów kości zwierzęcych. W. Szymański datował ten obiekt na wiek XIII (Szymański 1968).

Kolejnym, badanym przez nas stanowiskiem był kopiec w Małkowie. Znajduje się on na łąkach na lewym brzegu odnogi Warty, na wschód od nowożytnego założenia dworskiego. Nasyp ma wysokość około 3,5 m, a średnica jego górnej płaszczyzny to $9 \mathrm{~m}$. Otoczony był kiedyś nawodnioną fosą - obecnie zaobserwować można jedynie niewielkie obniżenie okresami zalewane. Prace rozpoczęto od próby odnalezienia śladów wykopu badawczego eksplorowanego w 1937 r. przez Gabriela Leńczyka. Ponieważ był on naniesiony jedynie na odręczny plan, nie można było posłużyć się pomiarami. Zlokalizowano pozostałości kilku wkopów. Jeden z nich, największy uznano za relikt wykopu 
G. Leńczyka. Jako że zajmował on kulminację stożka i przecinał znajdujące się tu typowe dla takich stanowisk zaklęśnięcie, postanowiono ulokować nowy wykop prostopadle do niego, czyli na osi z północnego zachodu na południowy wschód. Miał on wymiary 2 x 4 m i został wytyczony w taki sposób, aby jego krótszy bok - północno-wschodni znalazł się w pobliżu boku południowo-wschodniego wykopu z 1937 r.

Poniżej humusu, początkowo na całej badanej powierzchni, pojawiła się ciemna piaszczysta próchnica z niewielkimi wtrętami drobnych węgielków i stosunkowo licznymi zabytkami [2]. W części południowej miała ona znaczną grubość osiągającą $80 \mathrm{~cm}$, układała się w kierunku północnym równolegle do nachylenia stoków „kotlinki”, zmniejszając wyraźnie swoją miąższość tak, że przy narożniku północnym miała zaledwie około $35 \mathrm{~cm}$. W warstwie tej przy profilu południowo-zachodnim odnaleziono skupisko przedmiotów metalowych. Zalegały one około $50 \mathrm{~cm}$ pod powierzchnią ziemi, a część tkwiła w profilu wykopu. Po zakończeniu eksploracji, wykonaniu dokumentacji fotograficznej i rysunkowej, poszerzono w tym miejscu wykop, aby bezpiecznie wyjąć zabytki. Były to: ostroga z gwiaździstym bodźcem, grot bełtu z tuleją, zgrzebło, sierp i gwóźdź. Przedmioty te spoczywały na małej przestrzeni, w skupisku, którego średnica nie przekraczała $60 \mathrm{~cm}$ średnicy. Wydaje się, że mogły być one tu zdeponowane po wcześniejszych nieprofesjonalnych poszukiwaniach „skarbów”. Najwyraźniej nie okazały się dla znalazcy wystarczająco cenne i zakopał je w płytkim dole.

W północnej części wykopu, począwszy od głębokości około 99,41 m n.p.m., pojawiła się początkowo słabo wyodrębniona warstwa próchnicy o bardziej brunatnym zabarwieniu [3]. Tworzyła ona pas o szerokości 80 do $120 \mathrm{~cm}$ „odcinający" półkoliście północny narożnik wykopu, w którym z kolei znajdowała się gliniasta jaśniej zabarwiona warstwa [5]. Na podobnej głębokości w części południowo-zachodniej wykopu pod warstwą ciemnej, piaszczystej próchnicy z niewielkimi wtrętami drobnych węgielków i stosunkowo licznymi zabytkami [2], pojawił się jaśniejszy gliniasto-piaszczysty, twardy nasyp kopca [4].

Warstwa próchnicy o bardziej brunatnym zabarwieniu [3] zawierała w swoim składzie znaczne ilości przepalonej polepy. Trudno było w niej natomiast odnaleźć większe kawałki węgli drzewnych. Jednak o fakcie, że obiekt został zniszczony przez pożar informują również wtórnie przepalone fragmenty naczyń glinianych.

Przeprowadzone obserwacje pozwalają na wysunięcie przypuszczenia, że opisana warstwa [3], jest pozostałością zniszczonej ściany budynku. Niestety ślady są dosyć nietypowe - brak większej ilości węgla lub zbutwiałego drewna. Dopiero na głębokości około $96,90 \mathrm{~m}$ n.p.m. w miejscu, gdzie omawiana warstwa zajmowała niewielką część wykopu - w samym narożniku północnym - w jej obrąbie pojawiło się więcej popiołu (kolor zmienił się na szary), a jej zasięg od strony zewnętrznej ograniczała brązowa smuga zbutwiałego drewna. Niestety, 
układ ten miał niewielką miąższość, nieprzekraczającą $20 \mathrm{~cm}$. Poniżej zalegała próchnica pierwotna o grubości około $20 \mathrm{~cm}$, a pod nią piaszczysty calec.

Potwierdziliśmy więc częściowo obserwacje G. Leńczyka, który odkrył relikty drewnianej zabudowy, zniszczonej w wyniku pożaru, nie udało się nam natomiast zarejestrować śladów ,płotu na wale”, zasugerowanego w publikacji (Leńczyk 1937).

Ostatnim ze stanowisk badanych w 2014 r. był kopiec w Witowie. Grodzisko ulokowano w dolinie zalewowej Warty, na jej lewym brzegu. Powstało przez odcięcie od zaplecza części cypla wysoczyzny. Uformowany w ten sposób nasyp ma kształt zbliżony nieco do czworoboku o zaokrąglonych rogach oraz średnicę około $30 \mathrm{~m}$ i zachowaną wysokość 4,6 m. W roku 1964 badania wykopaliskowe przeprowadziła tu Janina Kamińska. Stwierdzono wówczas, że na nasypie funkcjonowała niezagłębiona budowla drewniana, po spaleniu której pozostały węgle drzewne i polepa. Odkryto klepisko o wymiarach 4 x $8 \mathrm{~m}$ na podkładzie z dranic (Kamińska, Golczyńska 1970). Niestety, w tym przypadku dane z publikacji nie do końca pokrywają się z naszymi obserwacjami. Dodatkowo, dokumentacja polowa, do jakiej udało nam się dotrzeć nie zachowała się w całości - brak jest planów. Do naszych rąk trafił jedynie dziennik polowy ${ }^{2}$. Po naszych weryfikacjach musimy jednak stwierdzić, że w świetle doświadczeń zgromadzonych przez prawie 50 lat badań podobnych obiektów, wnioski przedstawione we wspomnianej publikacji powinny być reinterpretowane ${ }^{3}$. Przede wszystkim w publikacji (Kamińska, Golczyńska 1970) przedstawiono plan z naniesionym 1 wykopem o wymiarach około 1,5 x $5 \mathrm{~m}$ - jest to najprawdopodobniej wynik źle narysowanej skali. W tekście znajdujemy informacje, że wykop miał długość $15 \mathrm{~m}$. W dzienniku polowym narysowano go tak, że jego wymiary wynoszą $4 \times 9 \mathrm{~m}$. Na wydrukowanym planie nie naniesiono drugiego wykopu „kontrolnego", o wymiarach 2 x 3 m, który w dzienniku polowym narysowano tak, że jego ściana południowa była przedłużeniem profilu północnego „głównego" wykopu na zachód, nakładając się na długości $1 \mathrm{~m}$.

W publikowanej wersji znajdujemy dość kategoryczne stwierdzenia o kilkucentymetrowej warstwie węgli czy „twardej przepalonej pokrywie brązowej gliny” i ,znacznej grubości zwalisku gliny, będącej może pozostałością pieca” (Kamińska, Golczyńska 1970: 162). Z lektury dziennika wynika tymczasem, że zaobserwowana stratygrafia była znacznie bardziej „wątła”, a ślady nie tak oczywiste.

Przystępując do badań mieliśmy jednak inne zmartwienie. Wiedzieliśmy już, że publikowany plan nie jest wiarygodny. Natomiast rysunki w dzienniku prze-

${ }^{2}$ Tu pragnę podziękować dyrektorowi Muzeum Archeologicznego i Etnograficznego w Łodzi prof. Ryszardowi Grygielowi za udostępnienie archiwalnej dokumentacji.

${ }^{3}$ Podobnie reinterpretację badań gródka w Podłężycach przeprowadził w 1995 r. Leszek Kajzer (1995). 
konywały, że w zasadzie prawie cały obszar plateau kopca został przebadany. Po wnikliwej obserwacji powierzchni zdecydowaliśmy się wytyczyć nasz wykop w południowej części plateau i stoku po osi północ - południe. Początkowo miał on wymiary $2,5 \times 4 \mathrm{~m}$. Szybko jednakże okazało się, że piaszczyste i piaszczysto-gliniaste warstwy zawierają nikłe ślady użytkowania. Nie odnaleziono żadnej polepy ani węgli drzewnych, które nadawałyby się do badań datujących. Wprawdzie dwie ciemniejsze warstwy miały w swoim składzie węgiel, jednak były to tak małe fragmenty, że pobranych próbek nie udało się wydatować. W nadziei odnalezienia większych konkrecji przedłużyliśmy wykop o $2 \mathrm{~m}$ na południe, niestety warstwy tam obserwowane były podobne.

W następnym - 2015 r. - badania przeprowadzono na kolejnych 4 stanowiskach.

Grodzisko w Kiełbowie Starym znajduje się na granicy pól i okresowo podmokłych łąk. Nasyp zbudowano na planie zbliżonym do koła o średnicy podstawy około $35 \mathrm{~m}$. Ma on kształt płasko ściętego stożka o wysokości 3,7 m. Otacza go fosa o szerokości wahającej się od 14 do $20 \mathrm{~m}$. Średnica grodziska łącznie z fosą na osi północ - południe to $72,5 \mathrm{~m}$, na osi wschód - zachód $67,5 \mathrm{~m}$. W partii szczytowej średnica wynosi około $21 \mathrm{~m}$. Pośrodku znajduje się nieckowate zaklęśnięcie o wymiarach 6 x 11,5 m, którego głębokość dochodzi do $1,5 \mathrm{~m}$. Woda w fosie utrzymuje się przez cały rok. W $1965 \mathrm{r}$. wykopaliska przeprowadził na tym stanowisku Zygmunt Włodzimierz Pyzik, natomiast w latach 1978-1979 trwały prace weryfikacyjne PPP PKZ kierowane przez Grzegorza Kotkowskiego. Plan z roku 1965 pochodził z publikacji (Pyzik 1970), jednak jego mała skala, brak punktów orientacyjnych i nieco zmieniona sytuacja terenowa spowodowały, że odnalezienie śladów wcześniejszego wykopu nie było łatwe. Miał on znaczne rozmiary $(2,5 \times 20 \mathrm{~m})$ i był poprowadzony po linii północ - południe. Ze względu na fakt, że autor naniósł go na plan dokładnie po środku plateau kopca, uznaliśmy, że jego śladem jest rozległe zaklęśnięcie w centralnej partii. Poszukiwanie śladów drugiego wykopu (z lat 70. XX w.) było jeszcze trudniejsze, ponieważ miał on zaledwie $0,8 \mathrm{~m}$ szerokości, przy $6 \mathrm{~m}$ długości. Według posiadanego przez nas planu pochodzącego ze sprawozdania G. Kotkowskiego wynikało, że ulokowano go w zachodniej części kopca po osi wschód - zachód. Śladów tego wykopu również nie można było odnaleźć. Niestety oba omawiane plany zostały wykonane w układzie lokalnym, więc wobec braku wyraźnych punktów orientacyjnych, nie było możliwe dokładne skoordynowanie ich z naszym planem. Dodatkowo cały teren zniszczony jest licznymi, nieregularnymi wkopami.

W opisanej sytuacji, postanowiliśmy wykop o wymiarach 2 × 3 m, ulokować przy krawędzi „kotlinki”, w części południowo-zachodniej kopca - na zachód od wykopu Z.W. Pyzika. Miejsce wybrano tak, aby obserwować zarówno nawarstwienia w tej części plateau, jak również stok „kotlinki”. 
Na głębokości około 20-30 cm zalegała warstwa sprawiająca wrażenie zasypiska, jednak bardzo duża ilość fragmentów naczyń (czasami znacznych rozmiarów), spowodowała, że nadal eksplorowaliśmy tę część, starając się wydzielić warstwy naturalne. Dopiero na głębokości około $0,7 \mathrm{~m}$ od powierzchni wykopu zarysowała się wyraźna, przy ścianie wykopu pionowa granica, która uświadomiła nam, że eksplorujemy dawny wykop Z.W. Pyzika. Trudno jest natomiast wytłumaczyć, dlaczego do zasypanego wykopu trafiły znaczne ilości fragmentów średniowiecznych naczyń.

Ponieważ wykop Z.W. Pyzika miał 2,5 m szerokości, postanowiliśmy nasz wykop II usytuować na wschód od niego. W tym celu przedłużyliśmy boki północny i południowy wykopu I o $4 \mathrm{~m}$ na wschód. Tym samym nowo wytyczony wykop II (po pozostawieniu $1 \mathrm{~m}$ świadka) uzyskał wymiary 2 x $3 \mathrm{~m}$.

Układ warstw był tu dość czytelny, jednak nie ma tu miejsca na jego dokładny opis. $Z$ istotnych informacji należy podać, że część północno-zachodnia wykopu, do głębokości dochodzącej do 1,5 m, została zniszczona zaraz po I wojnie światowej, kiedy zebrane z okolicznych pól niewybuchy i porzuconą amunicję zgromadzono na kopcu i zdetonowano. Najbardziej interesującą stratygrafię odkryto we wschodniej części wykopu. Przypominała ona sytuację zaobserwowaną w czasie badań kopca w Orszymowie. Pod warstwą ciężkiej gliny (1-1,3 m grubości), która osunęła się do wnętrza spalonego domu, zalegał (około 0,4 m) pokład gruzowy złożony z polepy, stopniowo zawierającej coraz więcej węgli drzewnych. Na głębokości 141,30-141,25 m n.p.m. odsłonięto relikty spalonej drewnianej podłogi, spoczywającej na niezbyt gęsto ułożonych kamieniach. Był to fragment (o szerokości około $1 \mathrm{~m}$ ) zachodniej części budynku.

Według Z.W. Pyzika na stanowisku zarejestrowano relikty dwufazowej zabudowy. Pierwszy drewniany dom miał mieć wielkość zbliżoną do obserwowanego na powierzchni plateau zaklęśnięcia tj. 6 x 11,5 m. Odkryto ponoć pozostałości konstrukcji drewnianych i ślad paleniska lub pieca o podstawie w kształcie elipsy o wymiarach 1 x 1,4 m. Budynek ten został zniszczony przez pożar. Zabudowania drugiej fazy wzniesiono na niwelacyjnej warstwie gliny. Podwyższono również nasyp stożka. $Z$ fazy tej zarejestrowano palenisko $\mathrm{z}$ otoczaków.

Jak wynika z naszych obserwacji, ustalenia te niestety nie potwierdziły się. Nie wiemy, co znajdowało się w centralnej części (pas o szerokości 2,5 m) zniszczonej przez wcześniejszy wykop. Z całą pewnością należy jednak wykluczyć możliwość istnienia tu budynku, o wymiarach sugerowanych przez Z.W. Pyzika. Dom, którego relikty odnaleźliśmy był usytuowany po wschodniej stronie plateau. Odkryte we wcześniejszych badaniach konstrukcje mogły być pozostałością po innym budynku funkcjonującym po zachodniej lub, co bardziej prawdopodobne, po południowej stronie kopca. Wskazuje to na istnienie zabudowy złożonej z kilku (co najmniej 2) domów wokół centralnego dziedzińca. Jest to sytuacja niezbyt często spotykana na obiektach typu motte. 
Kolejnym stanowiskiem, na którym prowadziliśmy badania weryfikacyjne było grodzisko w Piekarach. Ulokowane jest ono wśród łęgów nad Wartą. Dolna średnica stożka ma około $26 \mathrm{~m}$, górna zbliżona jest do $10 \mathrm{~m}$. Wysokość osiąga 2,8 m, a nasyp otacza słabo zachowana fosa. Wykopaliska w latach 1978-1979 przeprowadzili pracownicy Muzeum w Koninie. Niestety dokumentacja z tych badań zachowała się jedynie częściowo. Nasze wiadomości czerpaliśmy z pracy magisterskiej Jerzego Rybackiego (1984), który wykorzystał dokumentację polową. Z planu warstwicowego wynikało, że w 3 dużych wykopach na plateau odkryto drewniane relikty budynku. Dowiedzieliśmy się również, że elementy drewniane zachowane były u podstawy stożka w fosie. Ponieważ przeważająca część plateau jest już zniszczona, nasz wykop $(1$ x 2,5 m) ulokowaliśmy u podnóża kopca, po jego wschodniej stronie. Jak się należało spodziewać, nawarstwienia nie były zbyt skomplikowane. Poniżej humusu obserwowaliśmy spływowe warstwy próchniczne, a około $0,9 \mathrm{~m}$ od powierzchni pojawiły się osady denne fosy zawierające znaczne ilości materiału organicznego. W warstwie tej odkryliśmy fragment drewnianej belki i dwa kołki tkwiące w calcu. Z tych elementów pobraliśmy próbki do datowania.

Kolejne badania - w Sędziszowie - przyniosły chyba największe rozczarowanie. Gródek z zewnątrz prezentuje się niezwykle okazale - wysoki na około $8 \mathrm{~m}$ ma średnicę podstawy przekraczającą $30 \mathrm{~m}$. Ulokowany jest na skraju podmokłej doliny zalewowej potoku Lipka, prawego dopływu Mierzawy. Wykopaliska w 1980 r. przeprowadził tu Z.W. Pyzik. Z jego relacji wynika, że w warstwach na kulminacji kopca odkryto ,pokłady węgli drzewnych i polepy” (Pyzik 1980).

Spodziewając się licznych szczątków organicznych, zdecydowaliśmy się na otwarcie stosunkowo dużego wykopu $-2 \times 4 \mathrm{~m}$. Ponieważ nie udało nam się dotrzeć do planu z wcześniejszych badań, wykop wytyczyliśmy w miejscu najwyższym na plateau - wnioskując, że nie będzie zniszczone poprzednimi wykopaliskami. Pod humusem eksplorowaliśmy typowe warstwy nasypowe, jakie zazwyczaj występują na sztucznych nasypach. Nie odnaleźliśmy w nich żadnych materiałów zabytkowych, nie było również węgli ani polepy. Na głębokości od 1,8 do 1,5 m od powierzchni (około $205 \mathrm{~m}$ n.p.m.) pojawiła się mocno już przemyta ciemna piaszczysta warstwa, będąca śladem po spaleniu roślinności na pierwotnej powierzchni pagórka, na którym usypano kopiec. Jest to dość często obserwowana praktyka. Warstwa ta zalegała bezpośrednio na calcu. Nie udało się z niej pobrać próbek do badań.

Staraliśmy się odnaleźć wzmiankowane ,pokłady węgli drzewnych i polepy”. W tym celu przeprowadziliśmy szereg odwiertów geologicznym świdrem strzemiączkowym. Niestety, okazało się, że na całej powierzchni kopca, stratygrafia wygląda analogicznie do obserwowanej w wykopie. Nie wiemy, jak tę niespodziewaną sytuację wytłumaczyć. 
Ostatnim z badanych stanowisk był gródek w Szczekocinach. W czasie badań Z.W. Pyzika w 1969 r. (Pyzik 1969):

grodzisko znajdowało się wśród podmokłych łąk, rozciągających się na terasie zalewowej na lewym brzegu Pilicy. Kopiec ziemny w kształcie stożka o średnicy podstawy 30-33 m i wysokości $3 \mathrm{~m}$, otoczony był fosą szeroką na $10 \mathrm{~m}$. Bagnisty grunt, na którym zbudowano gród, umocniono bierwionami i wbitymi palami. Jądro nasypu wzniesiono z przemieszanego z próchnicą bagienną piasku, żwiru rzecznego i gliny. Płaszcz nasypu tworzy ziemia próchniczna

My zastaliśmy nieco inną sytuację terenową. Jak już wspomniano, prace związane z utworzeniem stawów hodowlanych zupełnie zmieniły krajobraz. Obszar stanowiska pozostawiono na sztucznie uformowanym, prostokątnym półwyspie. Jego przybliżone wymiary to 70 na $177 \mathrm{~m}$. Dłuższa oś przebiega po linii wschód - zachód. Istnieje także grobla łącząca ten teren z przeciwległym, wschodnim brzegiem stawu. U nasady półwyspu wykopany jest rów odwadniający w taki sposób, że dostanie się na grodzisko jest utrudnione. Całe jego otoczenie porasta wysoka na ponad $2 \mathrm{~m}$ roślinność bagienna, co nie sprzyja obserwowaniu powierzchni i stwierdzeniu, na ile jest ona zdegradowana. Nie można ponadto ocenić stanu fosy. Ponieważ teren jest mocno zniszczony przez zwierzęce nory i znajduje się na nim wiele kęp wytworzonych przez roślinność, wykonanie pomiarów do planu warstwicowego było bardzo trudne, a ich wyniki wymagały znacznej interpolacji. Na przetworzeniu LiDAR widoczne są zarysy fosy, która najlepiej zachowała się od strony południowo-wschodniej. Wydaje się jednocześnie, że wytyczono zbyt mały obszar ochrony, zwłaszcza od strony północnej - tam fosa najprawdopodobniej uległa zniszczeniu.

Niestety, po pracach Z.W. Pyzika nie pozostało w urzędzie konserwatorskim obszerniejsze sprawozdanie. Nie wiemy, czy w ogóle wykonano wówczas plan warstwicowy. Nie udało się również odnaleźć żadnych wskazówek, gdzie ulokowano 4 wykopy, o których wspomina badacz (Pyzik 1969). Nie posiadamy informacji, jaką powierzchnię objęły badania. Podjęliśmy próbę odnalezienia ewentualnych śladów po wykopach, co ze względu na stan terenu nie było łatwe. Zdecydowanie najmniej zniszczona wydawała się południowa część plate$a u$ kopca. Tam też ulokowaliśmy wykop sondażowy ( 2 x 4 m), którego zachodni, dłuższy bok pokrywał się z magistralą - narożnik północno-zachodni znalazł się na reperze A05.

Eksplorację rozpoczęto od zdjęcia warstwy humusu. Ku naszemu zaskoczeniu, odnaleźliśmy w nim stosunkowo dużą ilość fragmentów naczyń glinianych - 127 sztuk. Ponieważ teren ten najprawdopodobniej nigdy nie był orany, wydobycie do współczesnej warstwy próchnicznej tych przedmiotów trzeba uznać za dzieło archeologów prowadzących wcześniejsze badania. 
Zalegające poniżej warstwy nie różniły się od siebie w znaczący sposób. Jednak zarysowała się, początkowo słabo widoczna, ale wraz z pogłębianiem się wykopu, coraz wyraźniejsza, granica dwóch typów wypełniska.

W południowej części wykopu pojawiła się ciemna, piaszczysta próchnica z niewielkimi wtrętami drobnych węgielków w zasadzie pozbawiona zabytków [7]. Zajmowała ona południową część wykopu na przestrzeni około $180 \mathrm{~cm}$ od strony wschodniej i $160 \mathrm{~cm}$ od zachodniej. Dosyć szybko została ona zidentyfikowana jako wkop. Jednak jej nieregularne krawędzie (zwłaszcza przy profilu wschodnim) i fakt, że od tej strony wkop miał kształt wręcz „lejkowaty", spowodowały, że nie byliśmy w stanie stwierdzić, czy są to ślady wykopu Z.W. Pyzika. W czasie dalszej eksploracji okazało się, że wkop ten kończy się tuż przed południową ścianą naszego wykopu - zaobserwowaliśmy go na profilu południowym jedynie tuż pod humusem. W tej sytuacji można stwierdzić, że został on wykonany w czasach niemal współczesnych. Dodatkowo, u góry miał on szerokość niewiele przekraczającą 1,8 m (być może pierwotnie było to $2 \mathrm{~m}$ ) i był dłuższy niż $2 \mathrm{~m}$, gdyż nie zarejestrowaliśmy jego brzegów po linii wschód - zachód w naszym wykopie o tej właśnie szerokości. Jako że na profilach wschodnim i zachodnim nie znaleźliśmy jego południowej granicy, a jednocześnie na profilu południowym układ stratygraficzny był zupełnie inny, stwierdziliśmy, że opisywany wkop zniszczył istotną granicę między odmiennymi układami warstw kulturowych. W celu potwierdzenia tej obserwacji, powinno się poszerzyć wykop od strony południowej. Niestety nie mieliśmy na to czasu. Ze względów bezpieczeństwa nie mogliśmy też zmniejszyć skosów ściany południowej, ponieważ groziło to jej zawaleniem. Dlatego też, po zakończeniu eksploracji i narysowaniu wszystkich profili, podczyściliśmy ścianę południową. Okazało się, że granica wkopu przebiegała prawie dokładnie po linii ściany południowej naszego wykopu.

Wkop (wykop z 1969 r.?) nie doszedł do calca. W tym miejscu, zarówno pod wkopem, jak i na południe od niego, odnotowano na głębokości niwelacyjnej około 257,8 m n.p.m. warstwę nasypowego żółtego pisku ze żwirem [8]. Miała ona niewielką miąższość osiągającą około $20-30 \mathrm{~cm}$. Jest to zapewne jedna z warstw tworzących sztuczny nasyp. Nie odnotowaliśmy jej obecności w pozostałej części wykopu. Ta obserwacja dodatkowo potwierdza fakt istnienia odmiennego układu stratygraficznego w tej części plateau.

Na pozostałej części wykopu, poniżej warstwy humusu, zalegała nasypowa, szara próchnica $\mathrm{z}$ wtrętami białego pisaku [2]. Warstwa ta, na przeważającej części wykopu, miała miąższość około $80 \mathrm{~cm}$. Natomiast na profilu południowym osiągała około 1,5 m. Na głębokości około 258,57 m n.p.m. Obserwowaliśmy cienką warstwę spalenizny o grubości od 10 do $25 \mathrm{~cm}$. Poniżej zalegała gruba na około $1 \mathrm{~m}$ typowa warstwa nasypowa, często oglądana w sztucznych kopcach. Pod nią ponownie wystąpiła ciemna warstwa przesycona węglami 
drzewnymi, z której udało nam się pobrać próbki do badań datujących. Taki układ stratygrafii może sugerować dwufazowość tego stanowiska. Być może pierwsza z zarejestrowanych ciemnych warstw powstała na skutek pożaru funkcjonującej już siedziby, po którym teren uporządkowano i być może nieco nadsypano. Natomiast niższa - to typowy ślad porządkowania terenu poprzez spalenie zarośli - przed sypaniem kopca. Niestety zbyt mały zakres badań nie pozwolił na pewne rozstrzygnięcia. Zbiór, pozyskanych w czasie badań, fragmentów naczyń ceramicznych, liczący 178 sztuk, jest dość jednorodny. Jeżeli nasz wniosek o dwóch fazach zasiedlenia tego obiektu jest słuszny, musiały one nastąpić po sobie na tyle szybko, że nie zdążyły zajść istotne zmiany w technologii, a co za tym idzie, w wyglądzie naczyń.

Przejdźmy teraz do próby podsumowania opisanych badań weryfikacyjnych. W wyniku podjętych prac wykopaliskowych na sześciu stanowiskach udało się pozyskać próbki do badań datujących. Jedynie na stanowiskach w Witowie i Sędziszowie nie odnaleziono żadnych materiałów, które można by było poddać laboratoryjnym badaniom datującym. Starano się pobrać próbki do badań dendrochronologicznych, radiowęglowych $\left({ }^{14} \mathrm{C}\right)$ oraz termoluminescencyjnych. $\mathrm{Na}$ żadnym z badanych stanowisk nie udało się odnaleźć drewna do badań dendrologicznych. Do badań izotopu radioaktywnego węgla ${ }^{14} \mathrm{C}$ posłużyły próbki pozyskane na sześciu stanowiskach. Dla nich wykonano serie datowań. I tak dla Kiełbowa Starego i Małkowa uzyskano po 4 wyniki, dla Piekar 6, dla Szczekocin 5, najwięcej, bo 9 dat udało się wykonać dla Orszymowa, a zaledwie 2 dla Wilkanowa 4 .

Na podstawie otrzymanych wyników badań ${ }^{14} \mathrm{C}$, tylko dla dwóch stanowisk uzyskano daty, które pozwalają na potwierdzenie ich funkcjonowania w XIII w. - są to Małków i Orszymowo. Kolejne dwa stanowiska można datować na wiek XIV - Szczekociny i Kiełbów Stary, a materiały z Piekar uzyskały daty pozwalające sytuować użytkowanie obiektu w wieku XV. W przypadku Wilkanowa, standardowe obliczenia kalibracyjne dały datowania na czasy w pełni nowożytne. Jednak jedna z próbek, może być datowana na wiek XV (probability 91\%). Datowanie to jest jednakże kontrowersyjne, ponieważ Wilkanowo i Orszymowo to stanowiska oddalone od siebie o kilka kilometrów, a pozyskany w wyniku wykopalisk materiał ceramiczny wydaje się być bardzo podobny. Rozwiązanie tego problemu wymaga dalszych studiów.

W programie wyjściowym grantu ważnym sposobem pozyskania dat bezwzględnych było wykonanie datowań termoluminescencyjnych. Miały być one wykonane w laboratorium funkcjonującym na Uniwersytecie Marii Curie-Skłodowskiej w Lublinie, ale opisane na wstępie smutne wydarzenia spowodowały, że próbki musieliśmy wysłać do innego laboratorium. Niestety uzyskane wyniki

\footnotetext{
${ }^{4}$ Datowania zostały wykonane przez prof. dr hab. inż. Marka Krąpca.
} 
są całkowicie niezadowalające. Ich dokładność, jak na potrzeby archeologii, jest nie do zaakceptowania. Dodatkowo wskazane datowania dotyczą czasów w pełni nowożytnych - są więc niewiarygodne.

Pomimo to, można się jednak pokusić o sformułowanie pewnych wniosków. Praktyka wykazała, że badanie jedynie wykopów sondażowych w celu pobrania próbek nie zawsze jest skuteczne. Wiele zależy od dokumentacji sporządzonej w czasie wcześniejszych badań. Spotkaliśmy się tu z kilkoma problemami. Po pierwsze, plany sytuacyjno-wysokościowe stanowisk sprzed kilkunastu czy kilkudziesięciu lat najczęściej były wykonywane w układzie lokalnym czyli bez nawiązania do współrzędnych kartograficznych. Ponieważ bardzo często brak jest na nich wyraźnych elementów trwałych, które mogły zachować się do dnia dzisiejszego, ich zgranie z przygotowanymi przez nas planami nie zawsze było możliwe. Powodowało to trudności z wyznaczeniem lokalizacji wykopu w taki sposób aby, po pierwsze, ominąć wykopy poprzedników, a po drugie, wybrać takie miejsce, które na podstawie dotychczasowych badań dawało szansę na odkrycie warstw kulturowych, w których znajdować się mogły szczątki organiczne potrzebne do analiz. W takiej sytuacji uzyskanie dobrych wyników dla 6 z 8 badanych stanowisk należy uznać za sukces.

Próba weryfikacji datowań najwcześniejszych obronnych siedzib rycerskich udała się częściowo. Jedynie dwa $\mathrm{z}$ badanych stanowisk można faktycznie uznać za dwory z wieku XIII. Potwierdziliśmy tym samym, że tak wczesne datowania mogą być prawidłowe, i że już w XIII w. możnowładztwo fundowało obronne siedziby typu motte.

Kolejny wniosek, który wypływa z przeprowadzonych badań, jest jednak dość pesymistyczny - datowanie większości stanowisk (gródków „stożkowatych") powinno być zweryfikowane. Należy więc ostrożniej posiłkować się takimi datowaniami w badaniach osadniczych.

Doskonale wiemy, że tradycyjny tryb datowania artefaktów archeologicznych nie jest wystarczająco precyzyjny, aby mógł być wykorzystywany we współczesnej nauce. Trzeba położyć większy nacisk na pobieranie próbek do datowań i zapewnienia odpowiednich środków finansowych na wykonanie badań laboratoryjnych. Nie trzeba nikogo przekonywać, że ma to szczególne znaczenie w odniesieniu do późnego średniowiecza. Źródła pisane nie przekazują nam danych, na podstawie których moglibyśmy odtworzyć proces powstawania najwcześniejszych dworów rycerskich, a przecież ma on kluczowe znaczenie dla rekonstrukcji organizacji sieci osadniczej i sposobów zarządzania wielką własnością ziemską w średniowieczu. W tym przypadku to archeologia może dostarczyć nowych, decydujących danych.

Opisane powyżej kłopoty z uzyskaniem datowania termoluminescencyjnego spowodowały, że przystąpiliśmy do konkursu grantowego z projektem powołania Laboratorium Datowania Termoluminescencyjnego. Niestety nie otrzyma- 
liśmy finansowania. Nasza determinacja doprowadziła jednak do pozyskania funduszy z Uniwersytetu Łódzkiego. W chwili obecnej nasze laboratorium już działa - czekamy na wyniki badań kolejnych próbek. Mam nadzieję, ze niebawem datowania uzyskane z badań zabytków ceramicznych staną się w archeologii standardem.

\author{
Anna Marciniak-Kajzer \\ Instytut Archeologii \\ Uniwersytet Łódzki \\ ul. Narutowicza 65 \\ 90-131 Łódź \\ e-mail: akajzer@uni.lodz.pl
}

\title{
Bibliografia
}

Kajzer L. (1977), W kwestii identyfikacji i datowania ,,grodzisk stożkowatych”, „Kwartalnik Historii Kultury Materialnej”, r. 25, nr 3, s. 389-394.

Kajzer L. (1995), Btędy metody czy „,klopoty prenatalne”? Uwagi o archeologicznych badaniach małych założen obronnych, „Archaeologia Historica Polona”, t. 1, s. $185-193$.

Kajzer L. (1997), ,Wasko czy szeroko”. Uwagi o datowaniu stanowisk archeologicznych z czasów historycznych, „Archaeologia Historica Polona”, t. 6, s. 23-43.

Kajzer L. (1998), Pomiędzy faktami krajobrazowymi a źródtami historycznymi, czyli o tzw. grodziskach stożkowatych na Niżu Polskim, [w:] H. Kočka-Krenz, W. Łoziński (red.), Kraje Stowiańskie w wiekach średnich. Profanum i sacrum, Poznańskie Towarzystwo Przyjaciół Nauk, Poznań, s. 429-437.

Kamińska J., Golczyńska A. (1970), Kopiec w Witowie, [w:] J. Kamińska (red.), Rozwój osadnictwa w rejonie Burzenina nad Warta VI-XIV w., Ossolineum, Wrocław, s. $162-165$.

Leńczyk G. (1937), Kopce historyczne w powiecie sieradzkim, „Sprawozdania Polskiej Akademii Umiejętności”, t. 42, nr 8, s. 229-231.

Marciniak-Kajzer A. (2011), Średniowieczny dwór rycerski w Polsce. Wizerunek Archeologiczny, Wydawnictwo Uniwersytetu Łódzkiego, Łódź

Marciniak-Kajzer A. (2016), O dylematach zwiqzanych z datowaniem późnośredniowiecznych grodzisk, [w:] M. Grupa, A. Pydyn (red.), Od Torunia do Charkowa, Wydawnictwo Uniwersytetu Mikołaja Kopernika, Toruń, s. 175-186.

Nowakowski D. (2017), Ślaskie obiekty typu motte. Studium archeologiczno-historyczne, Wydawnictwo Instytutu Archeologii i Etnologii Polskiej Akademii Nauk, Wrocław.

Pyzik Z.W. (1969), Szczekociny, pow. Włoszczowa, „Informator Archeologiczny”, Badania 1969 , s. 396-397.

Pyzik Z.W. (1970), Grodzisko stożkowate w Kietbowie Starym, pow. Biatobrzegi, „Rocznik Muzeum Świętokrzyskiego”, t. 6, s. 461-485. 
Pyzik Z.W. (1980), Sprawozdanie z archeologicznych badań wykopaliskowych na grodzisku stożkowatym w Pile, gm. Sędziszów, woj. Kielce, przeprowadzonych $w$ okresie 14 lipca do 2 sierpnia 1980 r., Kielce, maszynopis dostępny w archiwum Wojewódzkiego Konserwatora Zabytków w Kielcach.

Rybacki J. (1984), Grodziska stożkowate w Woli Piekarskiej i Piekarach nad środkowa Warta, Poznań, maszynopis pracy magisterskiej.

Szymański W. (1966), Sprawozdanie z badań sondażowych grodzisk w miejscowościach: Biała, Orszymowo, Parzeń, Wilkanowo i Wyszogród (d. Drwały), pow. Płock w 1966 roku, „Sprawozdania Archeologiczne”, t. 20, s. 231-235.

Szymański W. (1968), Przyczynek do badań nad problematyka grodzisk stożkowatych (Orszymowo $i$ Wilkanowo w pow. ptockim), „Kwartalnik Historii Kultury Materialnej", r. 16, nr 1, s. 55-72.

Summary

\section{ARE THEY THE OLDEST INDEED - VERIFICATION TESTS OF THE EARLIEST DATED MOTTE-AND-BAILEY CASTLES}

The aim of the presented research is to verify the correctness of the dating of the motte structures which, as a result of earlier excavations, were considered the earliest defensive knight's seats in Poland - that is, they were dated to the 13th century. So far, the absolute dates were obtained for scarcely a few/a few dozen(?) such structures. However, they were not considered the oldest features.

As a result of the literature research, several sites representing typical motte-and-bailey castles which in the previous excavations were dated to the 13th century, were selected. Three of the sites in question were located in the Masovia region: Kiełbów Stary, Stara Błotnica commune; Orszymowo, Mała Wieś commune and Wilkanowo (formerly Nakwasin), also located in the Mała Wieś commune. The next two sites are located in the Łódzkie region - Witów, Burzenin commune and Małków, Warta commune. A further study was conducted in Sędziszów (now in the territory of the village of Piła) in the Świętokrzyskie region, in Piekary - Greater Poland, Dobra commune and in Szczekociny, Silesia.

A new geodetic surveying showed some changes in the state of preservation of the study features. Unfortunately, most of them reveal some traces of deepening destruction.

The excavations undertaken at six sites yielded samples for the dating studies. The only sites whose excavations provided no materials that could be subjected to laboratory dating tests were in Witów and Sędziszów. Attempts were 
made to collect samples for dendrochronological, radiocarbon $\left({ }^{14} \mathrm{C}\right)$ and thermoluminescence tests. No wood for dendrological research was found at any of the study sites. The samples obtained from six sites were used to measure the ${ }^{14} \mathrm{C}$ radioactive isotope. A series of dating was performed for the study sites. As a result, 4 dates were obtained for Kiełbów Stary and Małkowo, 6 - for Piekary and 5 - for Szczekociny. The highest number -9 dates - were obtained for Orszymowo, whereas for Wilkanowo only 2 dates were produced.

The results showed that only in the case of two sites the obtained dates confirm their functioning in the 13th century - they are Małkowo and Orszymowo. Another two sites - Szczekociny and Kiełbów Stary - can be dated back to the 14th century, while the dates obtained for the materials from Piekary justify placing the functioning of the feature in the 15th century. In the case of Wilkanowo, the standard calibration calculations produced dates which suggest that the sites represent the modern times. One of the samples, however, may be dated to the 15th century (probability: 91\%). Nonetheless, these dates are rather controversial, because Wilkanowo and Orszymowo are the sites situated several kilometres away from each other whilst the excavated pottery materials seem to be very similar. A solution to this problem requires further scrutiny.

The attempt to verify the dates produced for the earliest defensive knight's seats succeeded in part. Only two of the researched sites can in fact be considered to be the 13th century manors. Ipso facto we confirmed that such early dates may be correct, and that already in the thirteenth century, the nobles founded defensive motte-and-bailey castles. Our study clearly shows that the chronology of the earliest Polish knight's manors, determined on the basis of the previous excavations, should be verified. The results of our work prove that the traditional dating methods used for archaeological artefacts are not precise enough to be used in modern science. We need to put more emphasis on the matter of collecting samples for dating and providing adequate financial resources necessary to perform laboratory tests. 